\title{
Effect of Ku80 on the radiosensitization of cisplatin in the cervical carcinoma cell line HeLa
}

\author{
LIANG ZHUANG ${ }^{1}$, FEI LIU ${ }^{1}$, PING PENG ${ }^{1}$, HUIHUA XIONG ${ }^{1}$, HONG QIU ${ }^{1}$, \\ XIUGEN FU $^{1}$, ZHIPING XIAO ${ }^{1}$ and XIAOYUAN HUANG ${ }^{2}$ \\ ${ }^{1}$ Cancer Center; ${ }^{2}$ Cancer Biology Research Center, Tongji Hospital, Tongji Medical College, \\ Huazhong University of Science and Technology, Wuhan, Hubei 430030, P.R. China
}

Received September 2, 2016; Accepted September 15, 2017

DOI: $10.3892 / \mathrm{ol} .2017 .7304$

\begin{abstract}
Cisplatin chemotherapy in combination with radiotherapy is the primary therapeutic strategy for the treatment of cervical cancer; however, the underlying molecular mechanism for cisplatin radiosensitization remains unknown. The aim of the present study was to investigate the effect of Ku80, a DNA double-strand break (DSB) repair protein, on cisplatin radiosensitization in cervical cancer. The pre-established Ku80 suppression cervical cancer cell line $\mathrm{HeLa} / \mathrm{Ku} 80$-siRNA and the normal HeLa cell line underwent $6 \mathrm{MV}$ X-ray irradiation (6 Gy) individually or in combination with $5 \mu \mathrm{g} / \mathrm{ml}$ cisplatin treatment. Alterations in apoptosis, the cell cycle and $\gamma \mathrm{H} 2 \mathrm{AX}$ expression were detected. Following irradiation individually and combined with cisplatin, compared with normal HeLa cells, $\mathrm{HeLa} / \mathrm{Ku} 80$-siRNAexhibited an increased rate of apoptosis $(\mathrm{P}<0.05)$. It was identified that the earlier cisplatin was administered following irradiation, the higher the rate of apoptosis. Cell cycle analysis indicated that, following irradiation combined with cisplatin, the cells were arrested in $G_{1}$ and $S$ phase rather than in $\mathrm{G}_{2} / \mathrm{M}$ phase following irradiation alone. Microscopic imaging of immunofluorescence staining and western blotting identified that $\mathrm{HeLa} / \mathrm{Ku} 80$-siRNA cells exhibited more $\gamma \mathrm{H} 2 \mathrm{AX}$ foci remaining following treatment with irradiation and cisplatin, particularly in the group treated with 6 Gy irradiation for $1 \mathrm{~h}$ together with $23 \mathrm{~h}$ of exposure to cisplatin. Irradiation in combination with cisplatin promoted the apoptosis of HeLa cells in association with the inhibition of Ku80, and it was identified that the earlier cisplatin was administered following irradiation, the more apoptosis was induced. This maybe because irradiation combined with cisplatin is able to arrest cells in $\mathrm{G}_{1}$ and $\mathrm{S}$ phase to rapidly repair damaged DNA, and the lack of Ku80 induces
\end{abstract}

Correspondence to: Dr Xiaoyuan Huang, Cancer Biology Research Center, Tongji Hospital, Tongji Medical College, Huazhong University of Science and Technology, 1095 Jiefang Boulevard, Wuhan, Hubei 430030, P.R. China

E-mail: missxiaoyuan@126.com

Key words: small interfering RNA, Ku80, cervical carcinoma, radiosensitivity, cisplatin, radiosensitization, cell cycle the inability to repair DSB, resulting in increased apoptosis. The results of the present study suggest that Ku80 may be a potent molecular target in cisplatin radiosensitization.

\section{Introduction}

Cervical cancer is a common malignant tumor that has a detrimental impact on the life and health of women, particularly in developing countries. Surgery and radiotherapy are used to treat cervical cancer at stage IIA and earlier, whereas radiotherapy together with platinum chemotherapy sensitization constitutes the preferred treatment strategy for locally advanced (stage IIB and later) cervical cancer (1).

Cisplatin is a potent chemotherapeutic agent that has been used for decades to treat a variety of cancers, including cervical, testicular, head and neck, ovarian and lung cancer. Cisplatin interacts directly with multiple cellular components, including proteins, thiol-containing peptides and nucleic acids (2). Cisplatin-DNA adducts are responsible for the majority of the cytotoxic effects of cisplatin, distorting the DNA double helix, which is able to inhibit DNA replication and transcription to lead to cell cycle accumulation and apoptosis $(2,3)$. The intra-strand cisplatin-DNA adducts are repaired primarily by the nucleotide excision repair pathway $(4,5)$.

Irradiation is the primary therapy used for the treatment of cancer, whereas X-ray irradiation is the principal strategy in radiotherapy. X-ray irradiation induces a number of types of DNA lesion. DNA double-strand breaks (DSBs) are generally regarded as the most lethal of all DNA lesions following radiation and are repaired by two major repair pathways: Homologous recombination (HR) and non-homologous end-joining (NHEJ) (6). The ataxiatelangiectasia mutated protein serves a main function in HR and is only a pre-emergency DSB repair mechanism in human cells during late $S, G_{2}$ and $M$ phases, as the sister chromatid for replication is required as a template for repair (7). NHEJ is present at all times during the entire cell cycle, especially in $G_{0} / G_{1}$ and early $S$ phases $(7,8)$. The known NHEJ proteins include DNA-dependent protein kinase (DNA-PK), and ligase IV and its cofactor X-ray cross-complementary group 4 (XRCC4). DNA-PK is a serine/threonine kinase that contains a $\mathrm{Ku}$ heterodimer (Ku70 and Ku80; Ku80 is also known as Ku86) and a DNA-PK catalytic subunit (DNA-PKcs), and it is crucial in the maintenance of telomere stability $(9,10)$. 
The combination of cisplatin and ionizing radiation (IR) treatment represents a common modality for treating a variety of types of cancer, and the underlying molecular mechanism of cisplatin-sensitizing radiotherapy has been discussed previously: Myint et al (11) demonstrated that clinically applicable doses of cisplatin result in the radiosensitization of mammalian cells due to the inhibition of the function of NHEJ. Another previous study demonstrated that the cisplatin-IR synergistic interaction requires the DNA-PK-dependent NHEJ pathway to join DNA DSBs, and the presence of a cisplatin lesion in the DNA inhibits this pathway (12). In the absence of a functional NHEJ pathway, although the cells are hypersensitive to IR, there is no synergistic interaction with cisplatin. The function of NHEJ and even DNA-PKcs has been identified in the combination of cisplatin and IR; however, the function of Ku80 in this synergy remains largely undefined (13). The aim of the present study was to investigate the mechanism of radiosensitization of cisplatin by inhibiting the expression of Ku80 using the previously developed cervical carcinoma cell model HeLa with Ku80 silencing (14).

\section{Materials and methods}

Cell line and cell culture. The human cervical adenocarcinoma cell line HeLa was obtained from the China Center for Type Culture Collection (Wuhan, China). The HeLa/Ku80-siRNAcell line with Ku80 silenced by stable transfection with Ku80-targeted small interfering RNA, and it was confirmed that Ku80 protein expression was suppressed in the Ku80-siRNA stable cell line in our previous study (14). The cells were cultured in Dulbeccos modified Eagles medium (DMEM; Invitrogen; Thermo Fisher Scientific, Inc., Waltham, MA, USA) supplemented with $10 \%$ fetal bovine serum (FBS; Invitrogen; Thermo Fisher Scientific, Inc.), $50 \mathrm{U} / \mathrm{ml}$ penicillin and $50 \mu \mathrm{g} / \mathrm{ml}$ streptomycin. All cells were maintained in a humidified $37^{\circ} \mathrm{C}$ incubator containing $5 \% \mathrm{CO}_{2}$, fed every 2-3 days with complete medium (containing 10\% FBS).

Clonogenic survival assay. Cells were plated in triplicate on $60-\mathrm{mm}$ dishes at the required density to obtain between 50 and 100 colonies/dish and were allowed to attach for $24 \mathrm{~h}$. HeLa and HeLa/Ku80-siRNA cells were exposed to 0, 2, 3 , 4, 6 and 8 Gy X-ray radiation; the cells were cultured for between 10 and 14 days in $5 \% \mathrm{CO}_{2}$ to obtain viable colonies. Colonies were stained with $0.5 \mathrm{ml} 0.01 \%$ crystal violet (Sigma-Aldrich; Merck KGaA, Darmstadt, Germany) solution at room temperature for $1 \mathrm{~h}$ and enumerated using a light microscope (magnification, $\mathrm{x} 40$ ). A viable colony was defined as having at least 50 cells after 10 days of growth. Colonies were counted from each triplicate sample and presented as the mean \pm standard deviation (SD). The surviving fraction of treated cells was normalized to the plating efficiency of control (non-irradiated) cells. The cell survival ratio was obtained by means of clone formation. A one-hit multi-target model was fitted to the cell survival curve to calculate the dose quasithreshold (Dq), mean lethal dose (D0) and radiosensitivity parameter ( $\mathrm{N}$ value). Cell survival was also plotted as a function of dose and fitted using the linear quadratic model $S F=\exp \left(-\alpha D-\beta D^{2}\right)$, where $S F$ is the cell survival, $D$ is the radiation dose, and $\alpha$ and $\beta$ are constants. The surviving fraction of cells at $2 \mathrm{~Gy}$ (SF2) was calculated from the actual data when the cells received 2 Gy irradiation.

MTT assay to determine the proliferation rates of cells following exposure to cisplatin. HeLa and HeLa/Ku80-siRNA cells at the exponential phase of growth were plated in 96-well plates at a density of $1 \times 10^{4}$ cells/well and cultured in DMEM with $0,0.5,2,5,20$ and $50 \mu \mathrm{g} / \mathrm{ml}$ cisplatin (Sigma-Aldrich; Merck $\mathrm{KGaA}$ ) for $4 \mathrm{~h}$. The medium was replaced with cisplatin-free medium. In total, $\sim 10 \mu \mathrm{l}(5 \mathrm{mg} / \mathrm{ml})$ MTT (Sigma-Aldrich; Merck KGaA) was added to the wells when these cells were treated with cisplatin for $48 \mathrm{~h}$ and the plates were incubated in a $37^{\circ} \mathrm{C}$ incubator for $4 \mathrm{~h}$. The blue formazan dye that had formed was dissolved in $150 \mu \mathrm{l}$ dimethyl sulfoxide (Sigma-Aldrich; Merck KGaA). The absorbance (A) at $570 \mathrm{~nm}$ was recorded using an ELISA Multiskan reader (Thermo Fisher Scientific, Inc.). The inhibition rate was calculated as follows: Inhibition rate $(\%)=\left(1-\mathrm{A} / \mathrm{A}_{0 \mathrm{~h}}\right) \times 100 \%$. In addition, the $50 \%$ inhibitory concentration $\left(\mathrm{IC}_{50}\right)$ was defined as the medicine concentration at which half of all cells were killed.

Cell treatment and cell cycle analysis. The two cell lines were plated in 6-well plates at $3 \times 10^{5}$ cells/well, which corresponded to a density of between 70 and $80 \%$ at the time of treatment. Treatment was divided into three parts. In the first part, cells were exposed to 6 Gy $6 \mathrm{MV}$ X-ray radiation (300c Gy/min). To determine the rate of apoptosis and cell cycle distribution, cells were harvested following irradiation for $1,6,12$, 24, 48 and $72 \mathrm{~h}$. In the second part, cells were first cultured in DMEM with $5 \mu \mathrm{g} / \mathrm{ml}$ cisplatin for $4 \mathrm{~h}$, then the medium was replaced with cisplatin-free medium, and the cells were harvested for flow cytometric analysis following treatment with cisplatin for 6,12 and $24 \mathrm{~h}$. In the third part, the cells were exposed to X-ray radiation for $6 \mathrm{~Gy}$, then treated with $5 \mu \mathrm{g} / \mathrm{ml}$ cisplatin (exposure for $4 \mathrm{~h}$ ) for 23, 18 and $12 \mathrm{~h}$ following irradiation for 1, 6 and $12 \mathrm{~h}$. All the cells were exposed to X-ray radiation and cisplatin for $24 \mathrm{~h}$ in total, prior to harvesting for flow cytometric analysis. The harvested cells were washed with PBS and fixed in $75 \%$ ice-cold ethanol overnight at $-20^{\circ} \mathrm{C}$. Following washing in PBS again, the cells were treated with $50 \mu \mathrm{g} / \mathrm{ml}$ propidium iodide and $1 \mathrm{mg} / \mathrm{ml}$ RNase A for $30 \mathrm{~min}$ at $37^{\circ} \mathrm{C}$. Subsequent analyses of the rate of apoptosis (sub- $\mathrm{G}_{1}$ ) and cell cycle distribution were performed using CellQuest software (Version 5.1; BD Biosciences, Franklin Lakes, NJ, USA).

Microscopic imaging of immunofluorescence staining. HeLa cells were grown on culture slides for two days until the density increased to $50 \%$ at the time of treatment. Following the aforementioned treatments, cells were washed in PBS, fixed in $4 \%$ paraformaldehyde for $30 \mathrm{~min}$, permeabilized in $0.5 \%$ Triton $\mathrm{X}-100 / \mathrm{PBS}$ for $15 \mathrm{~min}$ and blocked in blocking buffer [1\% bovine serum albumin (BSA; Sigma-Aldrich; Merck KGaA, Darmstadt, Germany)] in PBS) for $30 \mathrm{~min}$. Immunostaining was performed using an anti-phosphorylated histone H2AX $\left(\gamma \mathrm{H} 2 \mathrm{AX} ;\right.$ Ser $\left.^{139}\right)$ antibody (mouse anti-human, monoclonal antibody, catalog no. 05-636, EMD Millipore, Billerica, MA, USA, at a dilution of 1:500) for $2 \mathrm{~h}$ at room temperature in a humidified chamber. Following three 10-min washes, the cells were incubated with the goat anti-mouse Alexa Fluor 568-conjugated 
secondary antibody (Invitrogen; Thermo Fisher Scientific, Inc.; catalog no. A11004, 1:1,000 dilution). The DNA was stained using a mounting medium with DAPI (Sigma-Aldrich; Merck KGaA). Immunofluorescence microscopic imaging was performed using a LSM 510 laser-scanning confocal microscope (Zeiss GmbH, Jena, Germany). All experiments were performed at least three independent times.

Western blotting. For western blotting analyses, the cell pellets were collected, and the total protein was isolated using M-PER $^{\mathrm{TM}}$ mammalian protein extraction reagent (Pierce; Thermo Fisher Scientific, Inc.). Protein concentrations were determined using a bicinchonic acid protein assay kit (Pierce; Thermo Fisher Scientific, Inc.), according to the manufacturers protocol. An equal amount of total protein $(30 \mu \mathrm{g})$ from each lysate was separated by SDS-PAGE (6-10\% gel). Subsequently, the separated proteins were transferred onto nitrocellulose membranes, which were then blocked with 5\% powdered non-fat milk in Tris-buffered saline containing Tween-20 (TBS-T) for $1 \mathrm{~h}$ at $37^{\circ} \mathrm{C}$. Samples were incubated with mouse anti-human antibodies against Ku80 (cat no. KuAb-2; NeoMarkers, Inc., Portsmouth, NH, USA; at a dilution of 1:2,000), $\gamma \mathrm{H} 2 \mathrm{AX}$ or $\beta$-actin (Santa Cruz Biotechnology, Inc., Dallas, TX, USA, 1:1,000 dilution) at $4^{\circ} \mathrm{C}$ overnight. Following washing with TBS-T four times for $10 \mathrm{~min}$ each, the nitrocellulose membranes were incubated with a goat anti-mouse secondary antibody (cat no. ZB-2305; OriGene Technologies, Inc., Rockville, MD, USA; at a dilution of 1:500) for $1 \mathrm{~h}$ at room temperature and washed with TBS-T four times for $10 \mathrm{~min}$ each. Immunodetection was performed using the SuperSignal West Fem to Maximum Sensitivity substrate (Pierce; Thermo Fisher Scientific, Inc.).

Statistical analysis. Results are presented as the mean \pm SD of at least three experiments, and a two-tailed unpaired Students $\mathrm{t}$-test was used to compare the statistical significance of the differences in data from the two groups. A one-hit multi-target model $\mathrm{SF}=1-\left(1-\exp \left(-\mathrm{D}_{0} / \mathrm{D}\right)\right)^{\mathrm{N}}$ was fitted to the cell survival curve to calculate Dq, D0 and N using SPSS software (version 10.0; SPSS, Inc., Chicago, IL, USA). The linear quadratic model $\mathrm{SF}=\exp \left(-\alpha \mathrm{D}-\beta \mathrm{D}^{2}\right)$ was fitted to the cell survival curve and $\alpha$, $\beta$ and SF2 were calculated from the actual data using Sigma plot software (version 10.0; Systat Software Inc., Chicago, IL, USA), which was also used for all statistical procedures. $\mathrm{P}<0.05$ was considered to indicate a statistically significant difference.

\section{Results}

Rates of apoptosis and the proportion of HeLa cells in $G_{2} / M$ phase with Ku80 silencing following $6 \mathrm{~Gy} X$-ray irradiation. A dose of $<4$ Gy is insufficient to induce DSBs, and a dose of $>10$ Gy is considered to be a lethal dose, prone to induce cell death rather than DSBs; therefore, the majority of researchers select a dose of between 4 and $10 \mathrm{~Gy}$ to irradiate cells, and $6 \mathrm{~Gy}$ was considered to be a suitable dose for inducing DSBs (15). Following 6 Gy IR for 1, 6, 12 and 24 h, HeLa/Ku80-siRNA and HeLa cells exhibited similar rates of apoptosis $(\mathrm{P}>0.05)$, whereas at 48 and $72 \mathrm{~h}$ after irradiation, the rates of apoptosis of HeLa/Ku80-siRNA cells were increased compared with those of HeLa cells $(48 \mathrm{~h}, \mathrm{t}=6.293, \mathrm{P}=0.003 ; 72 \mathrm{~h}, \mathrm{t}=8.282$, $\mathrm{P}=0.001$; Fig. 1A).
Following 6 Gy IR, the proportion of cells in $\mathrm{G}_{2} / \mathrm{M}$ phase gradually increased at 1, 6, 12 and $24 \mathrm{~h}$, from $\sim 15 \%$ following irradiation for $1 \mathrm{~h}$ to almost $70 \%$ following irradiation for $24 \mathrm{~h}$. However, no significant differences between the two cell lines were identified at these time points $(\mathrm{P}>0.05$; Fig. $1 \mathrm{~B}$ and C). The proportion of the two cell lines in $\mathrm{G}_{2} / \mathrm{M}$ phase were at their peak at $24 \mathrm{~h}$, but decreased at $48 \mathrm{~h}$ and increased again at $72 \mathrm{~h}$. The proportion of HeLa/Ku80-siRNA cells in $\mathrm{G}_{2} / \mathrm{M}$ phase was decreased compared with that of HeLa cells at 48 and $72 \mathrm{~h}$, but no significant difference between the two cell lines at these time points following irradiation was identified ( $\mathrm{P}>0.05$; Fig. 1B and C).

Radiobiological analysis of HeLa silencing of Ku80. SPSS and Sigma plot software were used to calculate the radiobiological characteristics from the actual data (Table I). The SF2 and $\mathrm{D}_{0}$ values of $\mathrm{HeLa} / \mathrm{Ku} 80$-siRNA cells were decreased compared with that of HeLa cells, which suggests that $\mathrm{HeLa} / \mathrm{Ku} 80$-siRNAcells exhibited more radiosensitivity than HeLa cells when Ku80 was silenced. The $\mathrm{N}$ value and Dq value of $\mathrm{HeLa} / \mathrm{Ku} 80$-siRNA cells were decreased compared with those of the HeLa cells, indicating that when the shoulder area of HeLa/Ku80-siRNA cells becomes smaller, the ability to repair sub-lethal damage is weakened; in addition, the $\alpha$ value of HeLa/Ku80-siRNA cells also increased significantly, which indicated increased radiosensitivity of cells by inhibiting DNA DSB repair induced by a single ionizing particle energy deposition. However, the $\beta$ value altered only minimally, which indicated that the inhibition of Ku80 had little influence on the repair of DSBs caused by double ionizing particle energy deposition.

Rate of apoptosis of cells following 6 Gy IR and/or treatment with $5 \mu \mathrm{g} / \mathrm{ml}$ cisplatin. According to the MTT assay results (Fig. 2A), the $\mathrm{IC}_{50}$ value of cisplatin for the HeLa cells was $(5.83 \pm 1.06) \mu \mathrm{g} / \mathrm{ml}$, whereas that for the HeLa/Ku80-siRNA cells was $(5.17 \pm 0.99) \mu \mathrm{g} / \mathrm{ml}$. No significant difference in the $\mathrm{IC}_{50}$ value between the two cell lines was identified $(\mathrm{t}=0.788$, $\mathrm{P}=0.475$ ), so the concentration of cisplatin applied thereafter was $5 \mu \mathrm{g} / \mathrm{ml}$, and the two cell lines were exposed to cisplatin for $4 \mathrm{~h}$ prior to replacement with fresh DMEM.

The rates of apoptosis of the two cell lines increased slowly following treatment with $5 \mu \mathrm{g} / \mathrm{ml}$ cisplatin for 6,12 and $24 \mathrm{~h}$ (Fig. 2B), and no marked differences in cisplatin sensitivity between the two cell lines at the different time points were identified $(\mathrm{P}>0.05)$.

The proportions of cells in the $\mathrm{G}_{2} / \mathrm{M}$ phase from the two cell lines treated with $5 \mu \mathrm{g} / \mathrm{ml}$ cisplatin for $0,6,12$ and $24 \mathrm{~h}$ were all $\sim 20 \%$, and no significant differences were identified between the two cell lines at various time points $(\mathrm{P}>0.05$; Fig. $2 \mathrm{C})$.

Nevertheless, following irradiation (6 Gy) and treatment with $5 \mu \mathrm{g} / \mathrm{ml}$ cisplatin $(4 \mathrm{~h})$, the rates of apoptosis of the two cell lines at all time points were distinct (Fig. 3A). First, when the two cell lines received 6 Gy IR and cisplatin treatment in combination, they exhibited increased rates of apoptosis compared with the cell lines that only received 6 Gy IR or $5 \mu \mathrm{g} / \mathrm{ml}$ cisplatin alone $(\mathrm{P}<0.05)$. Secondly, compared with normal HeLa cells, HeLa/Ku80-siRNAcells exhibited increased rates of apoptosis, particularly following 6 Gy IR for $1 \mathrm{~h}$ and treatment with $5 \mu \mathrm{g} / \mathrm{ml}$ cisplatin for $23 \mathrm{~h}$. The rate 
A

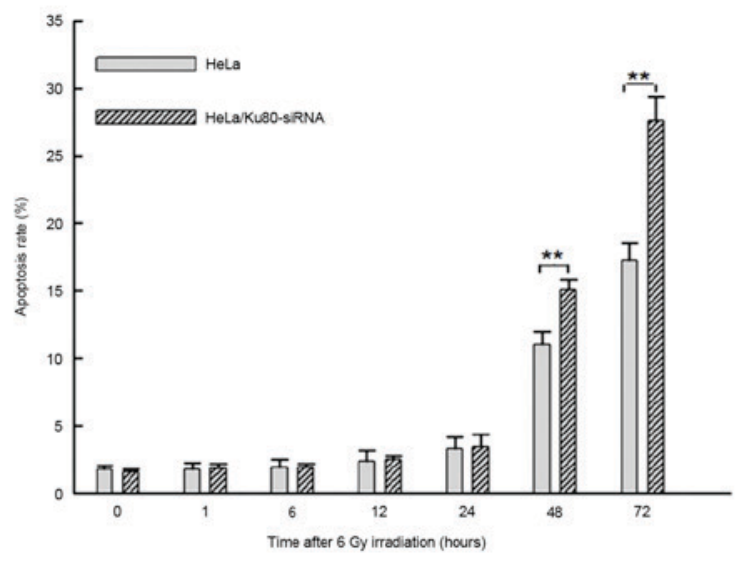

B

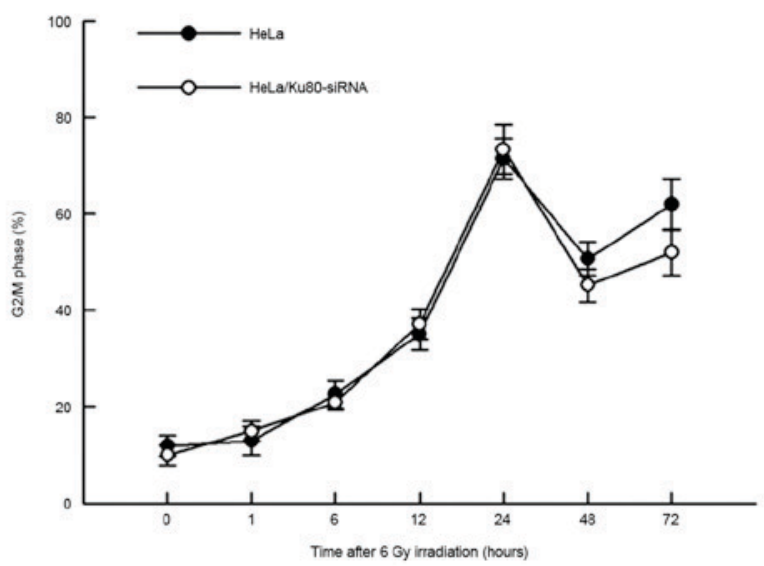

C
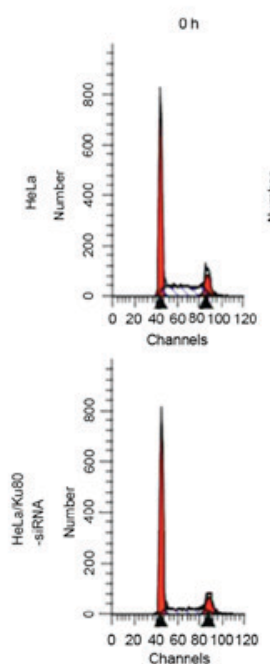
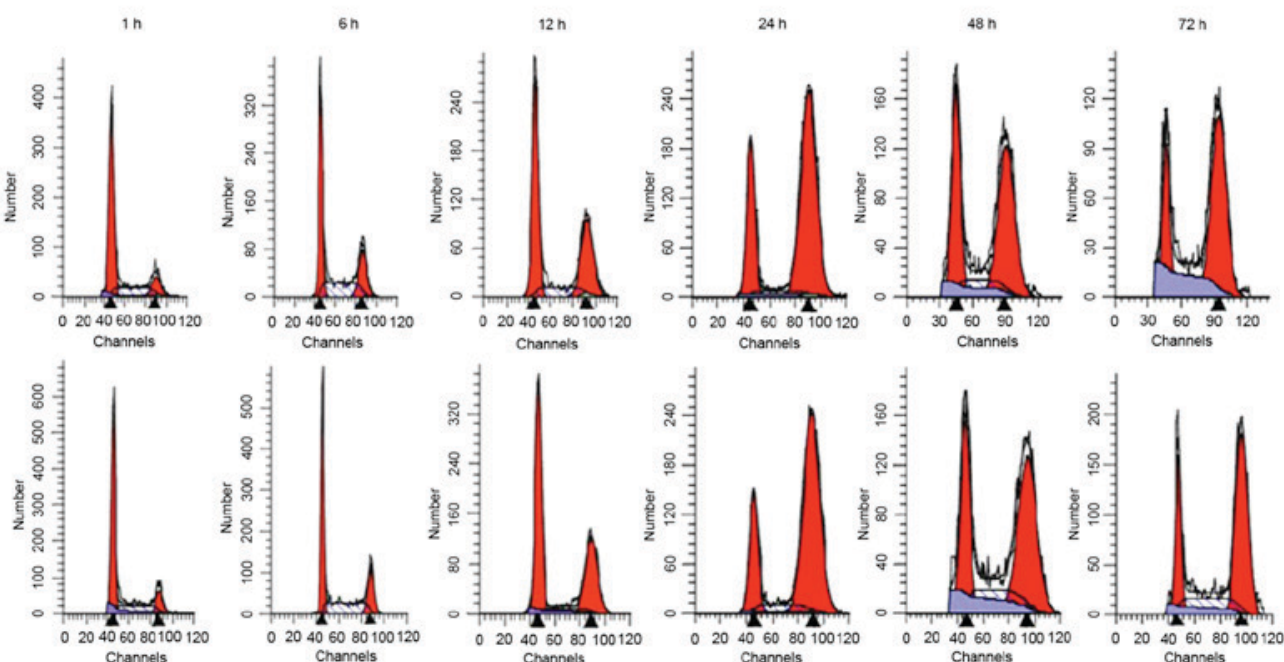

Figure 1. Rate of apoptosis and cell cycle variation of cells treated with 6 Gy irradiation. (A) HeLa and HeLa/Ku80-siRNA cells were exposed to 6 Gy X-ray radiation and were harvested $0,1,6,12,24,48$ and $72 \mathrm{~h}$ after irradiation. Rates of apoptosis (sub- $\mathrm{G}_{1}$ ) were determined using flow cytometry. ${ }^{* *} \mathrm{P}<0.05$. (B) The proportion of cells in $\mathrm{G}_{2} / \mathrm{M}$ phase following $6 \mathrm{~Gy}$ irradiation at different time points. (C) Results from one cell cycle experiment. Results are presented as the mean \pm standard deviation of three separate experiments.

of apoptosis of HeLa/Ku80-siRNA cells was $(11.92 \pm 1.02) \%$, which was markedly increased compared with that of normal HeLa cells $(6.56 \pm 0.56) \%,(t=7.637, P=0.002)$. The $\mathrm{HeLa} / \mathrm{Ku} 80$-siRNA cells exposed to $6 \mathrm{~Gy}$ irradiation for $6 \mathrm{~h}$ and treated with $5 \mu \mathrm{g} / \mathrm{ml}$ cisplatin for $18 \mathrm{~h}$ exhibited increased apoptosis compared with normal HeLa cells that received the same treatment; their rates of apoptosis were $(7.44 \pm 0.84) \%$ and $(5.43 \pm 0.42) \%$, respectively $(\mathrm{t}=3.707, \mathrm{P}=0.021)$. Similar results were obtained when the two cell lines were exposed to $6 \mathrm{~Gy}$ irradiation for $12 \mathrm{~h}$ and treated with $5 \mu \mathrm{g} / \mathrm{ml}$ cisplatin for $12 \mathrm{~h}$. The rates of apoptosis of HeLa/Ku80-siRNA and HeLa cells were $(7.08 \pm 0.63)$ and $(5.01 \pm 0.49) \%$, respectively $(\mathrm{t}=4.492, \mathrm{P}=0.011)$. These results revealed that, following Ku80 inhibition and 6 Gy IR, the earlier the cisplatin was administered, the more apoptotic HeLa cells appeared.

Alterations in the cell cycle following 6 Gy IR and/or treatment with $5 \mu \mathrm{g} / \mathrm{ml}$ cisplatin. Fig. 3B and C present the difference in the proportion of cells in the $\mathrm{G}_{2} / \mathrm{M}$ phase in the two cell lines following receipt of different treatments for $24 \mathrm{~h}$. The proportion of $\mathrm{G}_{2} / \mathrm{M}$ phase cells was $70 \%$ following a single
X-ray irradiation (6 Gy) for $24 \mathrm{~h}$, whereas the proportion was only $20 \%$ following the separate administration of $5 \mu \mathrm{g} / \mathrm{ml}$ cisplatin for $24 \mathrm{~h}$, similar to the cells without any treatment, which suggested that cisplatin treatment for $24 \mathrm{~h}$ does not cause $\mathrm{HeLa}$ cells to undergo $\mathrm{G}_{2} / \mathrm{M}$ cell cycle arrest. Following $6 \mathrm{~Gy}$ IR for $1 \mathrm{~h}$ plus cisplatin treatment for $23 \mathrm{~h}$, the proportion of $\mathrm{G}_{2} / \mathrm{M}$ phase cells remained close to $20 \%$. Following $6 \mathrm{~Gy} \mathrm{IR}$ for $6 \mathrm{~h}$ plus cisplatin treatment for $18 \mathrm{~h}$, the proportion of cells in $\mathrm{G}_{2} / \mathrm{M}$ phase increased to $30 \%$, whereas following 6 Gy IR for $12 \mathrm{~h}$ plus cisplatin treatment for $12 \mathrm{~h}$, the proportion of cells in $\mathrm{G}_{2} / \mathrm{M}$ phase further increased to $\sim 50 \%$. However, the differences between the two groups were not significant $(\mathrm{P}>0.05)$.

$\gamma H 2 A X$ phosphorylation in cells exposed to $6 \mathrm{~Gy} I R$ and/or cisplatin. At $24 \mathrm{~h}$ after treatment with $6 \mathrm{~Gy}$ IR and/or cisplatin, alterations in $\gamma \mathrm{H} 2 \mathrm{AX}$ phosphorylation were observed. There was no difference between the two cell lines following $6 \mathrm{~Gy}$ IR alone and cisplatin treatment alone; the two cell lines had few $\gamma \mathrm{H} 2 \mathrm{AX}$ foci remaining. However, when treated with $6 \mathrm{~Gy}$ IR and cisplatin, HeLa cells with Ku80 inhibition exhibited an increased number of remaining $\gamma \mathrm{H} 2 \mathrm{AX}$ foci, particularly 
Table I. Radiobiological parameters of cells detected using a clonogenic survival assay.

\begin{tabular}{lcccccc}
\hline Cell line & $\mathrm{D}_{0}, \mathrm{~Gy}$ & $\mathrm{~N}$ & $\mathrm{D}_{\mathrm{q}}, \mathrm{Gy}$ & $\mathrm{SF} 2$ & $\alpha$ & $\beta$ \\
\hline HeLa & $1.411 \pm 0.102$ & $2.917 \pm 0.178$ & $1.510 \pm 0.115$ & $0.548 \pm 0.020$ & $0.144 \pm 0.017$ & $0.078 \pm 0.006$ \\
HeLa/Ku80-siRNA & $1.117 \pm 0.060$ & $2.017 \pm 0.087$ & $0.783 \pm 0.040$ & $0.307 \pm 0.004$ & $0.444 \pm 0.008$ & $0.073 \pm 0.003$
\end{tabular}
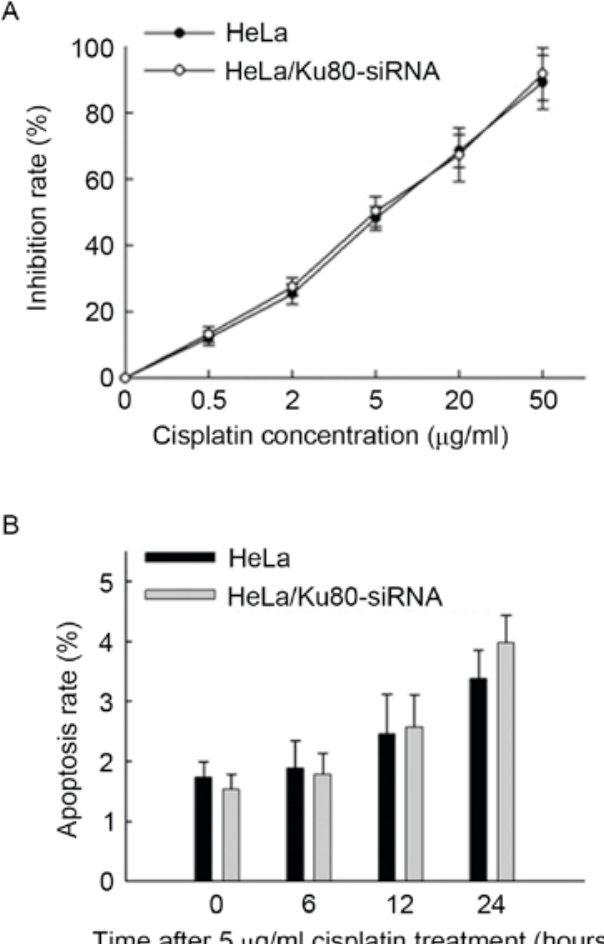

C

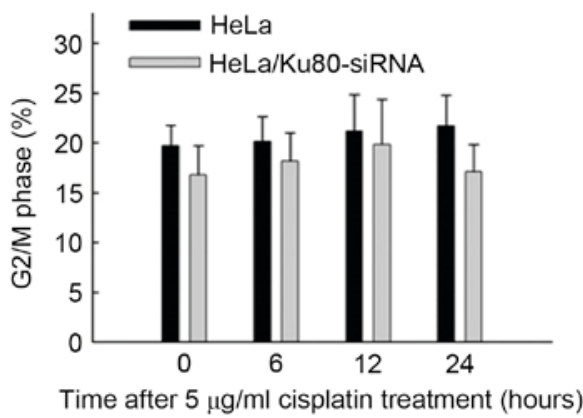

Figure 2. Effect of cisplatin on HeLa cells following Ku80 inhibition. (A) The inhibitory rate of cells treated with cisplatin determined using an MTT assay. No significant difference in the inhibition rate between the two cell lines was identified. (B) Rates of apoptosis (sub- $\mathrm{G}_{1}$ ) were analyzed using flow cytometry following cisplatin treatment. No significant differences in the rates of apoptosis between the two cell lines at all time points within $24 \mathrm{~h}$ were identified. (C) The proportion of cells in $\mathrm{G}_{2} / \mathrm{M}$ phase were at the almost same level $(\sim 20 \%)$, and no significant differences between HeLa and $\mathrm{HeLa} / \mathrm{Ku} 80$-siRNA cells at all time points within $24 \mathrm{~h}$ were identified. Results are presented as the mean \pm standard deviation of three separate experiments.

following 6 Gy IR for $1 \mathrm{~h}$ plus cisplatin for $23 \mathrm{~h}$, as presented in Fig. 4A and B. Western blotting also revealed the same results (Fig. 4C).

\section{Discussion}

The aim of the present study was to investigate the effect of $\mathrm{Ku} 80$ on cisplatin radiosensitization in cervical cancer. It was identified that irradiation in combination with cisplatin is able to promote the apoptosis of HeLa cells with the inhibition of $\mathrm{Ku} 80$, and the earlier cisplatin was administered following irradiation (with in $6 \mathrm{~h}$ ), the more apoptotic cells were induced. This suggests that Ku80 may be a potent molecular target of cisplatin radiosensitization, and the present study also provides evidence of the appropriate timing for cisplatin to sensitize radiotherapy.

DSBs are generally regarded as the most lethal of all DNA lesions following radiation; it is known that the NHEJ pathway serves a crucial function in repairing DSBs during radiation in mammalian cells. When DSBs are produced, the $\mathrm{Ku}$ heterodimer, which has a high affinity for DNA, is able to bind preferentially to the free DNA ends, possibly to prevent nuclease attack; subsequently, the conformation of $\mathrm{Ku}$ changes, allowing it to interact with the DNA-PKcs-Artemis complex. Following autophosphorylation, DNA-PKcs recruits the XRCC4-ligase IV complex to process the DNA ends and to initiate re-ligation to form a single DNA molecule (16). Ku80 is a major gene for DNA lesion repair. In the present study, the HeLa cell line with stable Ku80 inhibition using RNAi technology was used to investigate the alterations in radiobiological characteristics following IR. The results indicated that the rate of apoptosis of $\mathrm{HeLa} / \mathrm{Ku} 80$-siRNA cells following 6 Gy 6 MV X-ray irradiation at 48 and $72 \mathrm{~h}$ increased, whereas the SF2 and $D_{0}$ values obtained from clonogenic survival assays decreased. These results suggested that the HeLa cells with Ku80 inhibition become more radiosensitive, similar to the results of previous studies (17-19).

When DNA is damaged by radiation, the cell will initiate a cell cycle checkpoint signal transduction pathway. Individual cells arrest in $\mathrm{G}_{1}, \mathrm{~S}$ or $\mathrm{G}_{2} / \mathrm{M}$ phase to repair DNA lesions. Following DNA damage, there are three possible outcomes: i) Repair following injury and re-entry into the normal cell cycle; ii) apoptosis, which occurs when DNA damage is too severe and the cells cannot repair; and iii) tumor formation, in which cells proceed beyond the repair of damaged DNA and re-entry into the cell cycle (20). In the present study, the cell cycle of HeLa cells with Ku80 silenced and normal HeLa cells was analyzed. Following X-ray irradiation alone, the two cell lines appeared to be arrested in $\mathrm{G}_{2} / \mathrm{M}$ phase, and the number of cells arrested in $\mathrm{G}_{2} / \mathrm{M}$ phase gradually increased to reach a maximum at $24 \mathrm{~h}$ after irradiation, with a slight decline at $48 \mathrm{~h}$ and a second peak at $72 \mathrm{~h}$. It was observed that the proportion of cells in $\mathrm{G}_{2} / \mathrm{M}$ phase at $72 \mathrm{~h}$ following 6 Gy irradiation was increased compared with cells without irradiation. One possibility is that $6 \mathrm{~Gy}$ is not a lethal dose which 
A

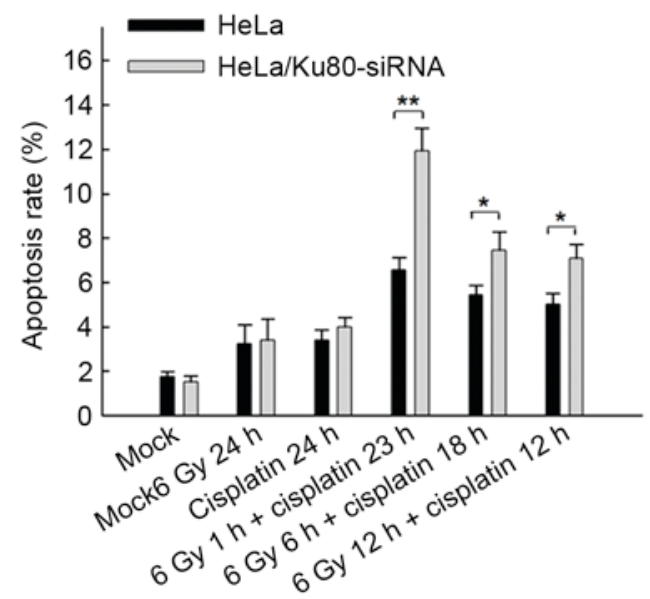

C
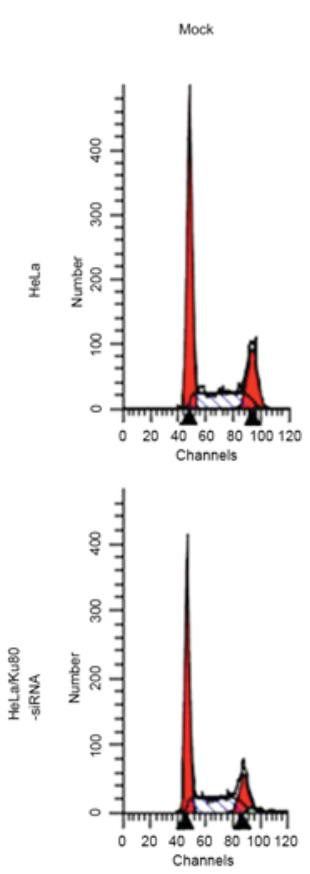

$6 \mathrm{~Gy} 24 \mathrm{~h}$
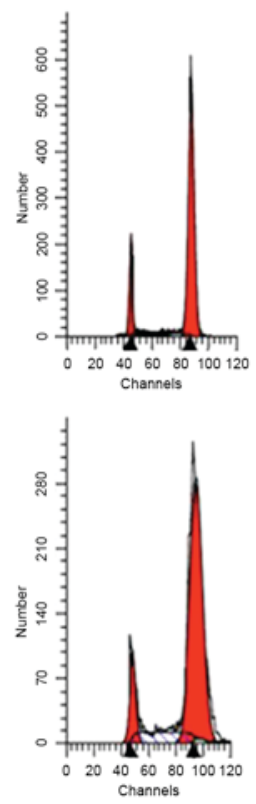

Cisplatin $24 \mathrm{~h}$
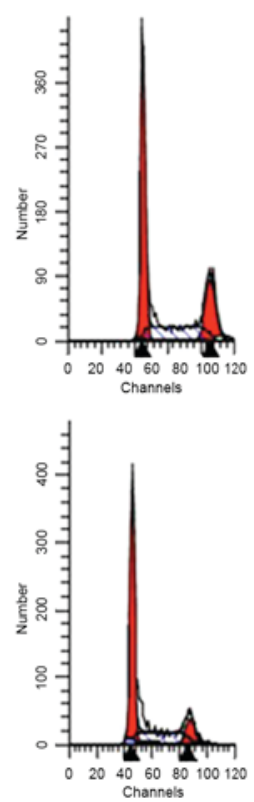
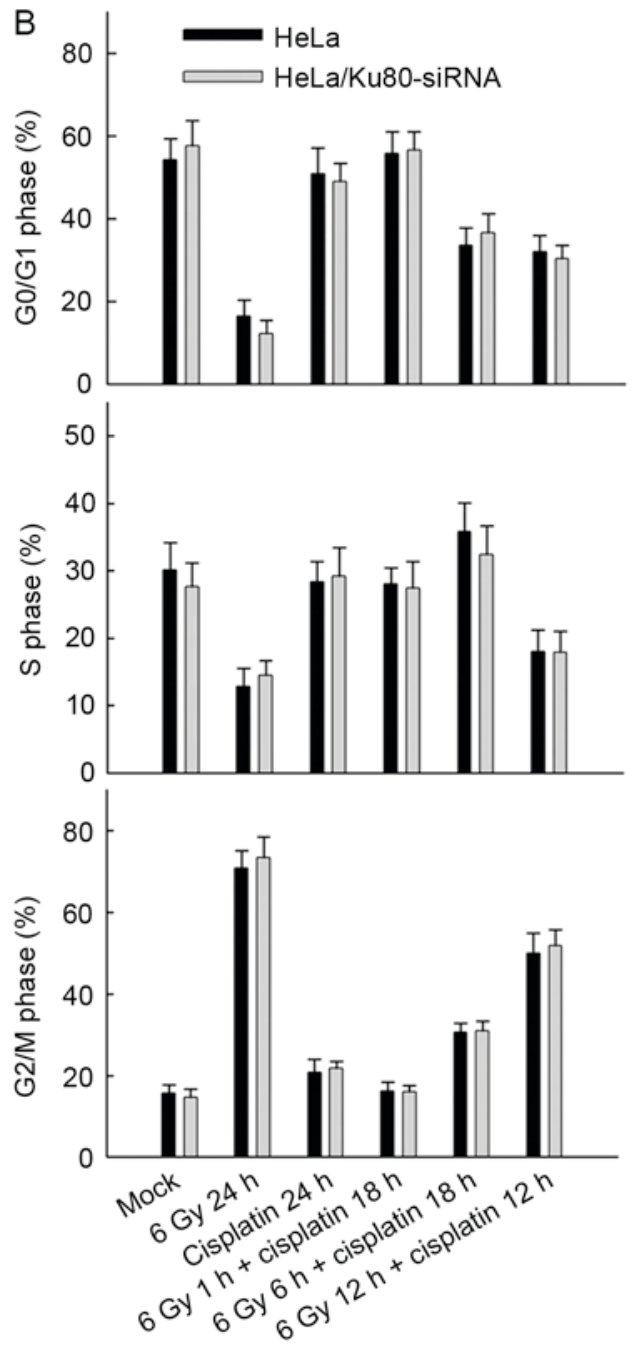

6 Gy 1 h+ cisplatin $23 \mathrm{~h}$

6 Gy $6 \mathrm{ht}+$

6 Gy $12 \mathrm{ht}$
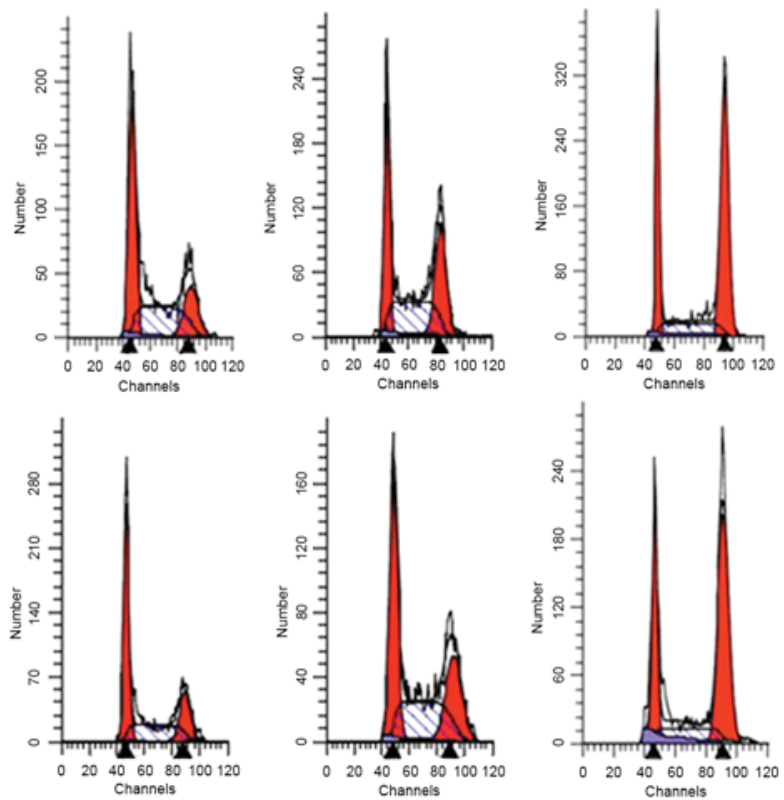

Figure 3. Rate of apoptosis and cell cycle variation of cells treated with 6 Gy irradiation and/or with $5 \mu \mathrm{g} / \mathrm{ml}$ cisplatin (exposed for $4 \mathrm{~h}$ ) within $24 \mathrm{~h}$. (A) HeLa and $\mathrm{HeLa} / \mathrm{Ku} 80$-siRNA cells were exposed to $6 \mathrm{~Gy}$ irradiation and/or treated with $5 \mu \mathrm{g} / \mathrm{ml}$ cisplatin $(4 \mathrm{~h})$ for a total of $24 \mathrm{~h}$, and apoptosis rates (sub-G $\mathrm{G}_{1}$ ) were analyzed using flow cytometry. ${ }^{*} \mathrm{P}<0.05,{ }^{* *} \mathrm{P}<0.01$. The rate of apoptosis of HeLa/Ku 80 -siRNA cells exposed to $6 \mathrm{~Gy}$ irradiation for $1 \mathrm{~h}$ and treated with $5 \mu \mathrm{g} / \mathrm{ml}$ cisplatin for $23 \mathrm{~h}$ was increased compared with that of HeLa cells $(P<0.01)$. (B) The proportion of cells in the $\mathrm{G}_{0} / \mathrm{G}_{1}, \mathrm{~S}$ and $\mathrm{G}_{2} / \mathrm{M}_{\mathrm{phases}}$ altered following $6 \mathrm{~Gy}$ irradiation and/or $5 \mu \mathrm{g} / \mathrm{ml}$ cisplatin treatment after $24 \mathrm{~h}$. (C) Data from one cell cycle experiment. Results are presented as the mean \pm standard deviation of three separate experiments. 

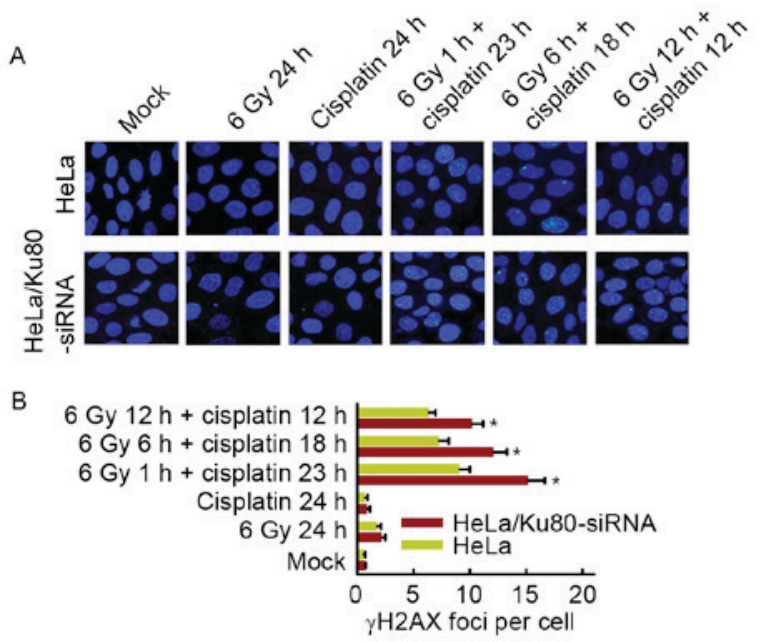

C

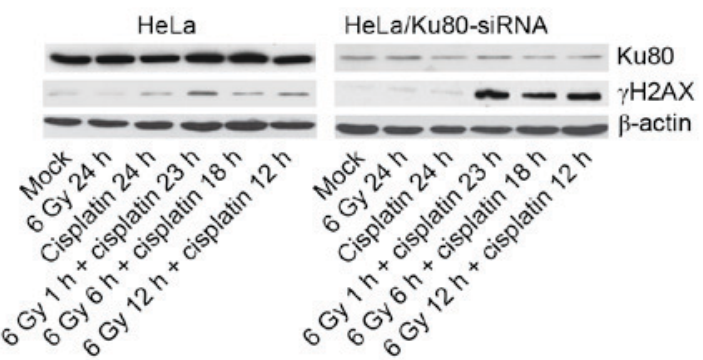

Figure 4. $\gamma \mathrm{H} 2 \mathrm{AX}$ phosphorylation in cells exposed to 6 Gy irradiation and/or cisplatin. (A) Microscopic imaging of immunofluorescence staining revealed that $24 \mathrm{~h}$ after treatment with $6 \mathrm{~Gy}$ ionizing radiation and/or $5 \mu \mathrm{g} / \mathrm{ml} \mathrm{cispl-}$ atin, there was no difference in $\gamma \mathrm{H} 2 \mathrm{AX}$ phosphorylation between HeLa and HeLa/Ku80-siRNA cells treated with 6 Gy irradiation alone and cisplatin alone $(\mathrm{P}>0.05)$; the two cell lines exhibited no or few remaining $\gamma \mathrm{H} 2 \mathrm{AX}$ foci. However, when treated with IR and cisplatin in combination, HeLa cells with Ku80 inhibition exhibited more $\gamma \mathrm{H} 2 \mathrm{AX}$ foci ( $\mathrm{P}<0.01)$, particularly in those treated with 6 Gy irradiation for $1 \mathrm{~h}$ plus cisplatin for $23 \mathrm{~h}$. (B) The number of $\gamma \mathrm{H} 2 \mathrm{AX}$ foci per cell following irradiation. Results are presented as the mean \pm standard deviation of three independent experiments. (C) Western blot analysis confirmed these results. $\gamma \mathrm{H} 2 \mathrm{AX}$, phosphorylated histone $\mathrm{H} 2 \mathrm{AX}$.

induces DSBs rather than cell death. Upon irradiation, cells are prone to arrest in $\mathrm{G}_{2} / \mathrm{M}$ phase to repair the DNA lesions and accumulate mostly at $24 \mathrm{~h}$. These cells gradually passed the $\mathrm{G}_{2} / \mathrm{M}$ arrest point and, following the entire duration of the cell cycle, became arrested in $\mathrm{G}_{2} / \mathrm{M}$ phase again at $72 \mathrm{~h}$ for detection and repair of the DNA lesions. However, a number of cells were not able to overcome the first $\mathrm{G}_{2} / \mathrm{M}$ arrest and resulted in apoptosis, whereas other cells repaired their DNA lesions completely and entered the normal cell cycle. Therefore, the number of $\mathrm{G}_{2} / \mathrm{M}$ phase cells at $72 \mathrm{~h}$ decreased. Furthermore, the proportion of $\mathrm{HeLa} / \mathrm{Ku} 80$-siRNA cells in $\mathrm{G}_{2} / \mathrm{M}$ arrest was decreased compared with that of HeLa cells at 48 and $72 \mathrm{~h}$ after irradiation, presumably due to the suppression of Ku80 and NHEJ repair pathway inhibition. These processes result in DNA damage that is beyond repair and more cells that undergo apoptosis, which is consistent with the increased rate of apoptosis of $\mathrm{HeLa} / \mathrm{Ku} 80$-siRNA cells at 48 and $72 \mathrm{~h}$ after 6 Gy IR.

Cisplatin is one of the most widely used chemotherapy agents to treat cancer, which is able to enhance the local control ratio and decrease the rate of metastasis in combination with radiotherapy in cervical cancer; however, its underlying molecular mechanism of action is not fully understood (21).
The present study identified that, compared with normal cells, HeLa cells lacking Ku80 expression exhibited no significant difference in the proliferation inhibition and rate of apoptosis when $5 \mu \mathrm{g} / \mathrm{ml}$ cisplatin was administered alone. This may be due to the lower level of DSBs caused by this concentration of cisplatin, which requires only limited or no NHEJ repair. Therefore, the use of cisplatin alone in Ku80-silenced HeLa cells did not significantly increase the rates of proliferation and apoptosis. Furthermore, the two cell lines treated with X-ray irradiation and $5 \mu \mathrm{g} / \mathrm{ml}$ cisplatin (exposed for $4 \mathrm{~h}$ ) in combination within $24 \mathrm{~h}$ were investigated. Following the administration of 6 Gy $6 \mathrm{MV}$ X-ray irradiation alone or $5 \mu \mathrm{g} / \mathrm{ml}$ cisplatin (exposed for $4 \mathrm{~h}$ ) alone for $24 \mathrm{~h}$, whether or not the Ku80 protein was suppressed, the rate of apoptosis of the two cell lines did not increase. However, the results were markedly different following treatment with IR and cisplatin together. First, the rate of apoptosis of cells following combination therapy was significantly increased compared with that following X-ray irradiation or cisplatin alone. Secondly, it was identified that the earlier cisplatin was administered after $\mathrm{X}$-ray irradiation (e.g. $1 \mathrm{~h}$ after irradiation), the higher the rate of apoptosis was achieved in HeLa cells with Ku80 inhibited. Additionally, the alterations in the cell cycle revealed that the earlier cisplatin was administered following irradiation, the more cells were arrested in $\mathrm{G}_{0} / \mathrm{G}_{1}$ and $\mathrm{S}$ phase; therefore, fewer cells were arrested in $\mathrm{G}_{2} / \mathrm{M}$ phase. A non-lethal dose of irradiation was able to arrest the cell cycle in $\mathrm{G}_{2} / \mathrm{M}$ phase to repair the DNA damage and induce cancer cell survival and radioresistance, which is the main focus of the present study. Whereas cisplatin treatment prior to irradiation was able to prevent DNA damage repair and decrease the proportion of cells in $\mathrm{G}_{2} / \mathrm{M}$ phase, particularly in DSB repair activity-impaired HeLa cells with Ku80 suppression, and it was identified that the earlier cisplatin was administered, the greater the number of cells killed.

The phosphorylation of $\mathrm{H} 2 \mathrm{AX}$ at $\operatorname{Ser}^{139}$ is a critical event in the series of early responses to IR-induced DNA DSBs (22). Because of its essential function in the DSB response, $\gamma \mathrm{H} 2 \mathrm{AX}$ is considered to be a sensitive biomarker for DSBs. In the present study, microscopic imaging of immunofluorescence staining and Western blotting were used to observe the change in $\gamma \mathrm{H} 2 \mathrm{AX}$ following various treatments. The results identified that, $24 \mathrm{~h}$ after treatment with IR and cisplatin, HeLa cells with Ku80 inhibition exhibited more $\gamma \mathrm{H} 2 \mathrm{AX}$ foci, particularly in the group with 6 Gy IR for $1 \mathrm{~h}$ plus cisplatin for $23 \mathrm{~h}$. These results suggested that the earlier cisplatin was administered following irradiation, the more DSBs remained. In this regard, preliminary studies have also provided some explanations: One demonstrated that $\mathrm{Ku}$ proteins (including $\mathrm{Ku} 80$ and $\mathrm{Ku} 70$ ) participate in cisplatin-DNA adduct repair (23); two other studies have identified that cisplatin exhibits its sensitizing effect due to the inhibition of the NHEJ pathway and by preventing DNA-PKcs protein phosphorylation, which resulted in a decrease in DSB repair $(11,12)$. A previous study also identified that cell killing by cisplatin occurs in a cell-autonomous manner by means of the formation of platinum-DNA adducts that, if not removed by DNA repair, inhibit transcription and replication, and damaged cells are able to transmit a death signal to neighboring cells (24). This signal produced within the cell is damaged by the kinase function of the Ku70, Ku80 and DNA-PK complex, and is conveyed to the 
recipient cell by direct cell-to-cell communication through gap junctions. However, these results only partially explained why cisplatin was able to sensitize cells to irradiation and did not explain why the earlier cisplatin is administered, the stronger the killing effect following X-ray irradiation. We hypothesize that the DNA damage of HeLa cells induced by X-ray irradiation with cisplatin formed the cisplatin-damaged DNA adducts to promptly repair the DNA damage (such as DSBs) in $\mathrm{G}_{1}$ and $\mathrm{S}$ phase, as the vast majority of DNA damage produced by irradiation is repaired within $6 \mathrm{~h}$ of radiotherapy (9). Therefore, the earlier cisplatin is administered within $6 \mathrm{~h}$, the greater the number of DSBs held in $\mathrm{G}_{1}$ and $\mathrm{S}$ phase for repair. The lack of Ku80 in HeLa cells with a damaged NHEJ repair pathway resulted in a larger proportion of apoptotic cells compared with normal HeLa cells. However, this hypothesis requires further investigation at the molecular level.

The results of the present study suggest that when patients receive either radiotherapy alone or combined cisplatin and radiotherapy, Ku80 was able to become a latent target for molecular therapeutics. A previous study demonstrated that $\mathrm{Ku} 80$ is highly expressed in a variety of tumor tissues, including cervical cancer (25). A number of studies not only noted that increased expression of Ku proteins indicated a poor prognosis in cervical cancer, head and neck cancer, hypopharyngeal cancer, lung cancer and other tumors, but also clinically demonstrated that cisplatin in combination with radiation is the principal treatment for these tumors (26-29). Therefore, inhibiting Ku80 may become a new therapeutic approach to promote the effective treatment of Ku80-expressingtumors (such as cervical cancer) combined with radiation and cisplatin. More importantly, the results of the present study suggest that cisplatin is able to maximize tumor killing as soon as possible after radiation and provides evidence of the appropriate timing for the administration of cisplatin to sensitize radiotherapy.

\section{Acknowledgements}

The present study was supported by the National Natural Science Foundation of China (grant nos. 81372434 and 81372664).

\section{References}

1. Petera J, Sirak I, Beranek M, Vosmik M, Drastikova M, Paulikova S and Soumarova R: Molecular predictive factors of outcome of radiotherapy in cervical cancer. Neoplasma 58: 469-475, 2011.

2. Kartalou M and Essigmann JM: Mechanisms of resistance to cisplatin. Mutat Res 478: 23-43, 2001.

3. Siddik ZH: Cisplatin: Mode of cytotoxic action and molecular basis of resistance. Oncogene 22: 7265-7279, 2003.

4. Wu X, Fan W, Xu S and Zhou Y: Sensitization to the cytotoxicity of cisplatin by transfection with nucleotide excision repair gene xeroderma pigmentosun group a antisense RNA in human lung adenocarcinoma cells. Clin Cancer Res 9: 5874-5879, 2003.

5. Guggenheim ER, Xu D, Zhang CX, Chang PV and Lippard SJ: Photoaffinity isolation and identification of proteins in cancer cell extracts that bind to platinum-modified DNA. Chembiochem 10: 141-157, 2009.

6. Wang $\mathrm{C}$ and Lees-Miller SP: Detection and repair of ionizing radiation-induced DNA double strand breaks: New developments in nonhomologous end joining. Int J Radiat Oncol Biol Phys 86 : 440-449, 2013

7. Collis SJ, DeWeese TL, Jeggo PA and Parker AR: The life and death of DNA-PK. Oncogene 24: 949-961, 2005.

8. Burma S and Chen DJ: Role of DNA-PK in the cellular response to DNA double-strand breaks. DNA Repair (Amst) 3: 909-918, 2004.
9. Lieber MR, Ma Y, Pannicke U and Schwarz K: Mechanism and regulation of human non-homologous DNA end-joining. Nat Rev Mol Cell Biol 4: 712-720, 2003.

10. Goodwin JF and Knudsen KE: Beyond DNA repair: DNA-PK function in cancer. Cancer Discov 4: 1126-1139, 2014.

11. Myint WK, Ng C and Raaphorst GP: Examining the non-homologous repair process following cisplatin and radiation treatments. Int J Radiat Biol 78: 417-424, 2002.

12. Boeckman HJ, Trego KS and Turchi JJ: Cisplatin sensitizes cancer cells to ionizing radiation via inhibition of nonhomologous end joining. Mol Cancer Res 3: 277-285, 2005.

13. Sears CR and Turchi JJ: Complex cisplatin-double strand break (DSB) lesions directly impair cellular non-homologous end-joining (NHEJ) independent of downstream damage response (DDR) pathways. J Biol Chem 287: 24263-24272, 2012.

14. Zhuang L, Yu SY, Huang XY, Gao QL, Xiong H and Leng Y: Effect of Ku80 expression inhibition by RNA interference on proliferation of cervical carcinoma cell line HeLa. Ai Zheng 26: 252-257, 2007

15. Jayakumar S, Bhilwade HN, Pandey BN, Sandur SK and Chaubey RC: The potential value of the neutral comet assay and the expression of genes associated with DNA damage in assessing the radiosensitivity of tumor cells. Mutat Res 748: $52-59,2012$

16. Valerie K and Povirk LF: Regulation and mechanisms of mammalian double-strand break repair. Oncogene 22: 5792-5812, 2003.

17. Williams GJ, Hammel M, Radhakrishnan SK, Ramsden D, Lees-Miller SP and Tainer JA: Structural insights into NHEJ: Building up an integrated picture of the dynamic DSB repair super complex, one component and interaction at a time. DNA Repair (Amst) 17: 110-120, 2014.

18. Gullo C, Au M, Feng G and Teoh G: The biology of Ku and its potential oncogenic role incancer. Biochim Biophys Acta 1765: 223-234, 2006

19. Zhuang L, Cao Y, Xiong H, Gao Q, Cao Z, Liu F, Qiu H, Yu S and Huang X: Suppression of DNA-PKcs and Ku80 individually and in combination: Different effects of radiobiology in HeLa cells. Int J Oncol 39: 443-451, 2011.

20. Melo J and Toczyski D: A unified view of the DNA-damage checkpoint. Curr Opin Cell Biol 14: 237-245, 2002.

21. Wieringa HW, van der Zee AG, de Vries EG and van Vugt MA: Breaking the DNA damage response to improve cervical cancer treatment. Cancer Treat Rev 42: 30-40, 2016.

22. Fillingham J, Keogh MC and Krogan NJ: GammaH2AX and its role in DNA double-strand break repair. Biochem Cell Biol 84: 568-577, 2006.

23. Turchi JJ and Henkels K: Human Ku autoantigen binds cisplatin-damaged DNA but fails to stimulate human DNA-activated protein kinase. J Biol Chem 271: 13861-13867, 1996.

24. Jensen R and Glazer PM: Cell-interdependent cisplatin killing by $\mathrm{Ku} / \mathrm{DNA}-d e p e n d e n t$ protein kinase signaling transduced through gap junctions. Proc Natl Acad Sci USA 101: 6134-6139, 2004.

25. Moll U, Lau R, Sypes MA, Gupta MM and Anderson CW: DNA-PK, the DNA-activated protein kinase, is differentially expressed in normal and malignant human tissues. Oncogene 18: 3114-3126, 1999.

26. Harima Y, Sawada S, Miyazaki Y, Kin K, Ishihara H, Imamura M, Sougawa M, Shikata N and Ohnishi T: Expression of Ku80 in cervical cancer correlates with response to radiotherapy and survival. Am J Clin Oncol 26: e80-e85, 2003.

27. Pavón MA, Parreño M, León X, Sancho FJ, Céspedes MV, Casanova I, Lopez-Pousa A, Mangues MA, Quer M, Barnadas A and Mangues R: Ku70 predicts response and primary tumor recurrence after therapy in locally advanced head and neck cancer. Int J Cancer 123: 1068-1079, 2008.

28. Hayashi J, Sakata KI, Someya M, Matsumoto Y, Satoh M, Nakata K, Hori M, Takagi M, Kondoh A, Himi $T$ and Hareyama M: Analysis and results of Ku and XRCC4 expression in hypopharyngeal cancer tissues treated with chemoradiotherapy. Oncol Lett 4: 151-155, 2012.

29. Ma Q, Li P, Xu M, Yin J, Su Z, Li W and Zhang J: Ku80 is highly expressed in lung adenocarcinoma and promotes cisplatin resistance. J Exp Clin Cancer Res 31: 99, 2012.

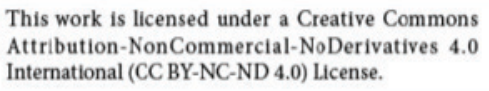
International (CC BY-NC-ND 4.0) License. 